\title{
Pengaruh Leverage, Working Capital Turnover, Kebijakan Dividen, dan Price Earning Ratio Terhadap Nilai Perusahaan Pada Perusahaan Consumer Goods Industry Yang Terdaftar Di Bursa Efek Indonesia
}

Hardi Citra

Universitas Prima Indonesia

hardi.citra@gmail.com

Rosniar

Universitas Prima Indonesia

Rosniarlim@gmail.com
Lola Felicia

Universitas Prima Indonesia felicia8412@gmail.com

\begin{abstract}
ABSTRAK
Tujuan dari penelitian ini adalah untuk membuktikan dan menganalisis pengaruh leverage, working capital turnover, kebijakan dividen, dan price earning ratio terhadap nilai perusahaan pada perusahaan barang konsumsi industri yang terdaftar di Bursa Efek Indonesia tahun 2014 - 2018. Populasi dalam penelitian ini adalah 49 perusahaan barang konsumsi industri yang terdaftar di Bursa Efek Indonesia tahun 2014- 2018. Dengan menggunakan teknik purposive sampling, didapat 18 perusahaan dengan dikalikan selama 5 tahun sehingga didapatkan 90 sampel penelitian. Hasil penelitian secara simultan dengan uji F menunjukkan bahwa variabel leverage, working capital turnover, kebijakan dividen dan price earning ratio secara bersama - sama berpengaruh terhadap nilai perusahaan. Hasil pembahasan dengan uji $\mathrm{T}$ menunjukkan bahwa variabel leverage, working capital turnover secara parsial tidak berpengaruh dan signifikan terhadap nilai perusahaan, sedangkan kebijakan dividen, dan price earning ratio berpengaruh secara parsial terhadap nilai perusahaan.
\end{abstract}

\section{Kata kunci : Leverage, Working Capital Turnover, Kebijakan Dividen, Price Earning Ratio, Nilai Perusahaan}

\section{Pendahuluan}

Pada dasarnya setiap perusahaan akan dihadapkan dengan berbagai tantangan maupun masalah yang berat dikarenakan semakin kompetitifnya persaingan antar perusahaan. Perusahaan memiliki banyak tujuan yaitu bukan hanya mempertahankan kelangsungan usahanya saja melainkan diharuskan memiliki keunggulan kompetitif dibandingkan perusahaan lainnya. Keunggulan tersebut akan terus bertumbuh apabila perusahaan mampu menghasilkan produk yang bermanfaat dengan meminimalisir pengeluaran biaya. Namun pada umumnya perusahaan memiliki tujuan yang utama dalam berupaya untuk mendapatkan keuntungan yang lebih besar dengan menggunakan sumber modal yang ada secara maksimal dan memfokuskan perhatiannya terhadap kesejahteraan bagi pemegang saham agar penilaian publik maupun investor akan semakin positif bagi perusahaan. Dalam menarik minat investor, 
perusahaan mengandalkan kemampuan manajemennya dalam mengambil tindakan yang bijaksana melalui peningkatan pada harga saham. Naiknya harga saham mengindikasikan bahwa saham tersebut sangat diinginkan oleh investor karena mereka percaya bahwa kinerja dan pencapaian perusahaan akan semakin stabil dan baik kedepannya bagi kesejahteraan pemegang saham. Keputusan berinvestasi seperti untuk membeli saham secara tepat bukanlah keputusan yang mudah. Ada banyak faktor yang harus dicurigai oleh investor salah satunya adalah memperkirakan expected return yang hasilnya akan menyimpang dari hasil yang diharapkan. Dengan informasi yang tepat tentang kinerja keuangan dengan rasio sebagai titik acuannya dapat membantu para calon investor untuk berinvestasi dan menilai saham secara tepat.

Pemilihan perusahaan consumer goods industry ini dikarenakan jenis usahanya bergerak dalam bidang produksi yaitu menyediakan barang - barang konsumsi yang dibutuhkan oleh masyarakat setiap harinya dan memiliki tingkat stabilitas laba yang selalu stabil setiap tahun serta harga saham di perusahaan ini cenderung lebih tinggi dibandingkan sektor - sektor perusahaan lain. Namun permasalahan utama yang ditemukan pada penelitian ini adalah turunnya harga saham secara dratis pada tahun 2015. Salah satu penyebabnya adalah naiknya kurs dollar Amerika Serikat, sehingga hal ini akan berimbas pada sebagian besar saham di pasar modal di Indonesia dikarenakan lemahnya kurs rupiah pada dollar AS di tahun 2015. Tercatat, sektor saham barang konsumsi yang biasa dapat bertahan ditengah kondisi ekonomi lesu malah susut sebesar 5,57\%. Dampaknya pun berpengaruh terhadap kinerja setiap emitennya, diantaranya KAEF sebesar 40,61\%, TSPC sebear 38,92\% dan MLBI sebesar 31,3\% menurun dari tahun 2014.

Peneliti

(Nurminda, Isynuwardhana, \& Nurbaiti, 2017) dalam penelitiannya yang berjudul "Pengaruh Profitabilitas, Leverage, dan Ukuran Perusahaan Terhadap Nilai Perusahaan". Hasil dari penelitian ini menyatakan bahwa leverage (DER) tidak memiliki pengaruh signifikan terhadap nilai perusahaan (PBV). Namun hasil penelitian bertentangan dengan peneliti (Sutama \& Lisa, 2018) dalam penelitiannya yang berjudul "Pengaruh Leverage dan Profitabilitas Terhadap Nilai Perusahaan". Hasil dari penelitian ini menyatakan bahwa leverage berpengaruh positif dan siginifikan terhadap nilai perusahaan.

Peneliti (Senja \& Wahyuni, 2017) dalam penelitiannya yang berjudul "Pengaruh WCT, Leverage, dan ROE Terhadap Nilai Perusahaan Properti dan Real Estate". Hasil dari penelitian ini menyatakan bahwa perputaran modal kerja be pengaruh negatif dan signifikan terhadap nilai perusahaan. Namun hasil penelitian ini bertentangan dengan peneliti (Warouw, Nangoy, \& Saerang, 2016) dalam penelitiannya yang berjudul "Pengaruh Perputaran Modal Kerja dan Profitabilitas Terhadap Nilai Perusahaan pada Perusahaan Farmasi di Bursa Efek Indonesia". Hasil penelitian ini menyatakan bahwa perputaran modal kerja tidak berpengaruh signifikan terhadap nilai perusahaan.

Peneliti (Sartini, L. P. N., \& Purbawangsa, I. B. A, 2014) dalam penelitiannya yang berjudul "Pengaruh Keputusan Investasi, Kebijakan Dividen Serta Keputusan Pendanaan Terhadap Nilai Perusahaan". Hasil penelitiannya mengatakan bahwa kebijakan dividen 
berpengaruh positif terhadap nilai perusahaan. Namun hasil penelitian ini bertentangan dengan peneliti (Sofia \& Farida, 2017) dalam penelitiannya yang berjudul "Pengaruh Kebijakan Dividen, Kebijakan Hutang, dan Keputusan Investasi Terhadap Nilai Perusahaan Pada Sektor Sub Sektor Perdagangan Besar Yang Terdaftar di Bursa Efek Indonesia". Hasil penelitiannya menunjukkan bahwa kebijakan dividen secara parsial tidak ada pengaruh yang signifikan terhadap nilai perusahaan.

Peneliti (Lebelaha, D. L. A., \& Saerang, I. S, 2016) dalam penelitiannya yang berjudul "Pengaruh Price Earnings Ratio, Debt to Equity Ratio dan Dividend Payout Ratio Terhadap Nilai Perusahaan Pada BUMN Yang Terdaftar di Bursa Efek Indonesia" Hasil penelitiannya mengungkapkan bahwa price earnings ratio memiliki pengaruh yang signifikan terhadap nilai perusahaan" Namun hasil ini bertentangan dengan peneliti (Languju, O., Mangantar, M., \& Tasik, H. H. D, 2016) dalam penelitiannya yang berjudul "Pengaruh Return on Equity, Ukuran Perusahaan, Price Earning Ratio, dan Struktur Modal Terhadap Nilai Perusahaan Pada Perusahaan Property dan Real Estate Terdaftar di Bursa Efek Indonesia". Hasil penelitiannya mengungkapkan bahwa price earning ratio tidak berpengaruh signifikan terhadap nilai perusahaan.

\section{Tinjauan Pustaka \\ 2.1 Leverage}

(Hasna, 2014) mengatakan bahwa leverage merupakan suatu pengukuran efektivitas dari penggunaan utang dalam menentukan seberapa besar keuntungan maupun kerugian yang dapat diperoleh perusahaan. Indikator yang digunakan untuk menghitung leverage dapat dinyatakan dengan rumus :

$$
\mathrm{DER}=\frac{\text { Total Liabilities }}{\text { Total Equity }}
$$

\subsection{Working Capital Turnover}

(Noor, 2017) mengatakan bahwa working capital turnover digunakan untuk menilai seberapa kali aktiva lancar yang berputar untuk menghasilkan penjualan netto. Indikator yang digunakan untuk menghitung working capital turnover dapat dinyatakan dengan rumus :

Perputaran Modal Kerja= Penjualan Bersih

$\overline{\text { Aktiva Lancar - Hutang Lancar }}$

\subsection{Kebijakan Dividen}

(Senata, 2016) mengatakan bahwa kebijakan dividen merupakan pembayaran keuntungan perusahaan untuk para pemegang saham ekuivalen dengan banyaknya saham perusahaan. Indikator yang digunakan untuk menghitung kebijakan dividen dapat dinyatakan dengan rumus :

$$
\mathrm{DPR}=\frac{\mathrm{DPS}}{\mathrm{EPS}}
$$

\subsection{Price Earning Ratio}

(Languju, O., Mangantar, M., \& Tasik, H. H. D, 2016) mengatakan bahwa price earning ratio menunjukkan berapa besar investor mengukur harga sebuah saham terhadap kelipatan earningnya. Menurut Indikator yang digunakan untuk menghitung price earning ratio dapat dinyatakan dengan rumus :

$$
\mathrm{PER}=\frac{\text { Harga Saham }}{\text { Earning PerShare }}
$$

\subsection{Nilai Perusahaan}

(Ferina, Tjandrakirana, \& Ismail, 2015) mengatakan bahwa nilai perusahaan 
merupakan harga saham yang bersedia dibeli investor apabila perusahaan menjualnya. Indikator yang digunakan untuk menghitung nilai perusahaan dapat dinyatakan dengan rumus :

$$
\mathrm{PBV}=\frac{\text { Harga Saham }}{\text { Nilai Buku Saham }}
$$

\subsection{Pengaruh Leverage Terhadap Nilai Perusahaan}

(Rudangga, I. G. N. G., \& Sudiarta, G. M, 2016) mengatakan bahwa rasio leverage yang tinggi mengartikan bahwa nilai perusahaan dimata investor juga akan semakin tinggi, karena perusahaan dianggap memiliki kemampuan dalam mengatasi banyaknya kewajiban jangka panjang dengan cara melakukan pelunasan tepat pada jatuh tempo.

(Novari \& Lestari, 2016) menyatakan bahwa penggunaan utang yang melewati batas cenderung akan berdampak pada berkurangnya manfaat dari penggunaan utang karena perusahaan yang menerima manfaat menjadi tidak sama dengan biaya yang ditimbulkan, sehingga jumlah utang yang sedikit akan mendatangkan nilai perusahaan yang semakin membaik.

(Chandra \& Djajadikerta, 2017) mengatakan bahwa keberadaan utang dapat memberikan respon positif dari investor bahwa perusahaan memiliki kemampuan yang baik dalam memperbesar nilai perusahaan. Peningkatan penggunaan utang juga sering dianggap sebagai kemampuan perusahaan dalam membagikan hasil pengembalian lebih bagi pihak investor dengan tidak mengurangi proporsi kepemilikannya terhadap sebuah perusahaan.

H1 : Leverage berpengaruh terhadap nilai perusahaan

\subsection{Pengaruh Working Capital Turnover Terhadap Nilai Perusahaan}

(Agusentoso,

mengemukakan bahwa besarnya dana yang diperoleh perusahaan akan memperbesar profitabilitas artinya perusahaan memiliki kemampuan untuk mengelola dana tersebut untuk mendatangkan keuntungan yang semakin besar yang diikuti dengan kenaikan pada nilai perusahaan karena jika sebuah perusahaan memiliki profit yang tinggi maka investor pun akan semakin percaya terhadap perusahaan tersebut.

(Warouw, Nangoy, \& Saerang, 2016) mengatakan bahwa apabila modal kerja yang berputar secara cepat maka modal kerja tersebut dikelola perusahaan secara efisien dan sebaliknya. Keefisienan dari tingkat perputaran modal kerja akan mempermudah perusahaan untuk menjalankan aktivitas operasinya dan mendatangkan situasi yang menguntungkan bagi perusahaan. Oleh sebab itu, semakin cepat perputaran modal kerja maka nilai perusahaan cenderung naik karena ketertarikan investor terhadap saham akan semakin bertambah.

(Senja \& Wahyuni, 2017) menyatakan bahwa keefisienan dari suatu perusahaan dapat dilihat dari cepatnya perputaran modal kerja yang akan meningkatkan rentabilitas dan nilai perusahaan. Jika penjualan perusahaan lebih tinggi dari modal kerja maka perputaran modal kerjanya menjadi lebih cepat artinya perusahaan telahmelakukan aktivitasnya dengan baik. Dengan adanya aktivitas ini maka akan mendatangkan kondisi yang menguntungkan bagi perusahaan baik berupa peningkatan pada rentabilitas maupun nilai perusahaannya.

$\mathrm{H} 2$ : Working capital turnover berpengaruh terhadap nilai perusahaan. 


\subsection{Pengaruh Kebijakan Dividen Terhadap Nilai Perusahaan}

(Ilhamsyah \& Soekotjo, 2017) mengatakan bahwa laba yang diperoleh dari capital gain lebih disukai pemegang saham karena dalam memperoleh capital gain diperlukan waktu relatif cepat daripada pembayaran dividen memerlukan rentang waktu yang relatif lebih lama untuk memperolehnya, sehingga pembayaran dividen bagi pemegang saham akan mengakibatkan rendahnya nilai perusahaan.

(Setyani, 2018) mengatakan bahwa besarnya pembagian dividen akan menjadi faktor utama dalam menarik perhatian investor karena dividen lebih disukai investor dimana dividen umumnya bersifat lebih pasti dibandingkan mengharapkan capital gain yang memiliki sifat kurang pasti dalam memperolehnya. Dengan adanya perhatian investor yang melakukan pemodalan dana untuk perusahaan maka akan menyebabkan peningkatan pada harga saham dan nilai perusahaan.

(Sartini, L. P. N., \& Purbawangsa, I. B. A, 2014) mengatakan bahwa semakin besar pembayaran dividen dari laba neto perusahaan maka akan menimbulkan sebuah sinyal bagi perusahaan. Sinyal ini biasanya merupakan sinyal yang baik bagi perusahaan karena mendatangkan kondisi yang menguntungkan berupa meningkatnya laba perusahaan. Efek dari meningkatnya laba ini akan memperbesar harga saham pada pasar modal dan secara bersamaan akan menjadikan nilai perusahaan semakin positif.

H3 : Kebijakan dividen berpengaruh terhadap nilai perusahaan.

\subsection{Pengaruh Price Earning Ratio} Terhadap Nilai Perusahaan

(Lebelaha, D. L. A., \& Saerang, I. S, 2016) mengatakan bahwa semakin besar price earning ratio akan mengindikasikan bahwa harga per lembar saham dan nilai perusahaan juga akan semakin besar, akibatnya saham tersebut dapat dikategorikan ke dalam blue chip pada pasar modal.

(Arifianto \& Chabachib, 2016) mengatakan bahwa saham yang memiliki price earning ratio yang besar akan mencerminkan bahwa saham tersebut memiliki harga mahal terhadap pendapatan bersih per sahamnya, sehingga pertumbuhan laba di masa mendatang akan semakin bagus dalam menarik perhatian investor untuk melakukan pemodalan bagi perusahaan.

(Prasetyorini, 2013) mengatakan bahwa rendahnya price earning ratio akan mengirimkan sinyal bagi investor untuk membeli saham perusahaan karena saham tersebut berpotensi naik di masa mendatang yang berarti laba dan nilai perusahaan dalam kondisi bagus.

H4 : Price earning ratio berpengaruh terhadap nilai perusahaan

\section{Metode Penelitian}

\subsection{Metodologi Penelitian}

Penelitian ini termasuk metode kuantitatif dengan menggunakan data sekunder yang diperoleh dari website resmi Bursa Efek Indonesia. Jenis penelitian yang digunakan adalah penelitian deskriptif yang memberikan gambaran secara sistematis tentang informasi ilmiah yang berasal dari subjek atau objek penelitian (Sanusi, 2012). Sifat penelitian yang digunakan adalah hubungan kausal dimana menjelaskan hubungan sebab akibat antara variabel bebas dengan variabel terikat (Sugiyono, 2012). Adapun teknik pengumpulan data yang digunakan adalah dokumentasi yang berdasarkan kejadian historis perusahaan berupa arsip dengan format elektronik atau 
mempelajari literatur seperti buku dan laporan penelitian.

\subsection{Populasi dan Sampel}

Populasi penelitian ini adalah 49 perusahaan sektor consumer goods industry yang terdaftar di Bursa Efek Indonesia pada tahun 2014 - 2018. Teknik sampling yang digunakan adalah purposive sampling dengan kriteria sebagai berikut:

1. Perusahaan sektor consumer goods industry yang terdaftar di Bursa Efek Indonesia tahun 2014 - 2018.

2. Perusahaan sektor consumer goods industry yang mempublikasikan laporan keuangan secara lengkap di Bursa Efek Indonesia tahun 2014 2018.

3. Perusahaan sektor consumer goods industry yang memberikan dividen pada tahun $2014-2018$

Tabel 1. Kriteria Pengambilan Sampel Penelitian

\begin{tabular}{|c|c|c|}
\hline No. & Kriteria & $\begin{array}{l}\text { Jumlah } \\
\text { Sampel }\end{array}$ \\
\hline 1. & $\begin{array}{l}\text { Perusahaan sektor consumer } \\
\text { goods industry yang terdaftar di } \\
\text { Bursa Efek Indonesia tahun } \\
2014-2018 \text {. }\end{array}$ & 49 \\
\hline 2. & $\begin{array}{l}\text { Perusahaan sektor consumer } \\
\text { goods industry yang tidak } \\
\text { mempublikasikan laporan } \\
\text { keuangan secara lengkap di } \\
\text { Bursa Efek Indonesia pada } \\
\text { tahun } 2014-2018 \text {. }\end{array}$ & (11) \\
\hline 3. & $\begin{array}{l}\text { Perusahaan sektor consumer } \\
\text { goods industry yang tidak } \\
\text { memberikan dividen pada } \\
\text { tahun } 2014-2018 \text {. }\end{array}$ & $(20)$ \\
\hline \multirow{2}{*}{\multicolumn{2}{|c|}{$\begin{array}{c}\text { Jumlah Sampel } \\
\text { Jumlah Pemilihan Sampel (5 tahun } \\
\text { x 18) }\end{array}$}} & 18 \\
\hline & & 90 \\
\hline
\end{tabular}

\section{Hasil dan Pembahasan}

4.1 Statistik Deskriptif

Berdasarkan data sampel yang telah diperoleh maka dilakukan analisis statistik deskriptif untuk mengetahui nilai minimum, maksimum, rata - rata, maupun standar deviasi setiap variabel. Hasil analisis statistik deskriptif dapat dilihat di bawah ini sebagai berikut :

Tabel 2. Statistik Deskriptif

\begin{tabular}{|l|r|r|r|r|r|}
\hline & \multicolumn{7}{|c}{ Descriptive Statistics } \\
\hline DER & Minimum & Maximum & Mean & Std. Deviation \\
WCTO & 90 & .07 & 2.65 & .7270 & .58569 \\
DPR & 90 & .14 .92 & 35.48 & 3.1669 & 7.29504 \\
PER & 90 & .08 & 1.54 & .5318 & .31598 \\
PBV & 90 & 1.66 & 60.89 & 24.9096 & 12.54808 \\
Valid N (listwise) & 90 & .72 & 82.44 & 8.4866 & 14.32301 \\
\hline
\end{tabular}

\subsection{Uji Asumsi Klasik}

\subsubsection{Uji Normalitas}

Bertujuan untuk menguji apakah dalam model regresi, variabel pengganggu atau residual memiliki distribusi normal (Ghozali, 2011). Analisis statistik dilakukan dengan Uji KolmogorovSmirnov, jika nilai signifikansi $>0,05$ maka data residual berdistribusi normal. Hasil dari pengujian analisis statistik Kolmogrov - Smirnov adalah sebagai berikut :

Tabel 3. One - Sample Kolmogorov Smirnov Test Setelah Tranformasi One-Sample Kolmogorov-Smirnov Test

\begin{tabular}{|ll|r|}
\hline & & $\begin{array}{c}\text { Unstandardized } \\
\text { Residual }\end{array}$ \\
\hline $\mathrm{N}$ & Mean & 80 \\
Normal Parameters & $0 \mathrm{E}-7$ \\
& Std. Deviation & .55420999 \\
& Absolute & .057 \\
Most Extreme Differences & Positive & .057 \\
& Negative & -.055 \\
Kolmogorov-Smirnov Z & & .506 \\
Asymp. Sig. (2-tailed) & & .960 \\
\hline a. Test distribution is Normal. & \\
b. Calculated from data. &
\end{tabular}


Berdasarkan tabel diatas dapat dilihat bahwa nilai Asymp. Sig. (2-tailed) diatas 0,05 atau diatas 5\% yakni 0,960, maka dapat disimpulkan bahwa hasil uji normalitas Kolmogorov - Smirnov menunjukkan bahwa data berdistribusi secara normal.

\subsubsection{Uji Multikoliniearitas}

Bertujuan menguji apakah model regresi baik yang ditemukan adanya korelasi yang seharusnya tidak terjadi korelasi di antara variabel independen. Jika variabel bebas memiliki nilai tolerance lebih dari 0,10 dan nilai VIF kurang dari 10, maka disimpulkan tidak terjadi masalah multikolenieritas (Ghozali, 2011). Hasil dari pengujian multikoliniearitas yang digunakan dalam penelitian ini adalah sebagai berikut :

\section{Tabel 4. Uji Multikolinieritas Setelah Transformasi}

\begin{tabular}{|c|c|c|c|}
\hline \multicolumn{4}{|c|}{ Coefficients $^{a}$} \\
\hline \multirow{2}{*}{\multicolumn{2}{|c|}{ Model }} & \multicolumn{2}{|c|}{ Collinearity Statistics } \\
\hline & & Tolerance & VIF \\
\hline \multirow{4}{*}{1} & LN_DER & .483 & 2.071 \\
\hline & LN_WCTO & .523 & 1.912 \\
\hline & LN_DPR & .730 & 1.369 \\
\hline & LN_PER & .971 & 1.030 \\
\hline
\end{tabular}

a. Dependent Variable: LN_PBV

Berdasarkan tabel uji multikolinieritas diatas dapat disimpulkan bahwa nilai tolerance variabel debt to equity ratio sebesar 0,483 ; working capital turnover sebesar 0,523; dividend payout ratio sebesar 0,730; dan price earning ratio sebesar 0,971 lebih besar dari 0,1. Nilai VIF untuk debt to equity ratio sebesar 2,071; working capital turnover sebesar 1,912; dividend payout ratio sebesar 1,369; dan price earning ratio sebesar 1,030; lebih kecil dari 10, maka dapat ditarik kesimpulan bahwa data tidak terjadi masalah pada uji multikolinieritas.

\subsubsection{Uji Autokorelasi}

Untuk mengukur terjadinya gangguan korelasi atau penyebab ada tidaknya autokorelasi karena kesalahan spesifikasi (Ghozali, 2011). Uji ini dapat diukur berdasarkan nilai Durbin Watson yang diperoleh, jika du $<\mathrm{dw}<4-\mathrm{du}$, maka disimpulkan tidak ada masalah autokorelasi.

\section{Tabel 5. Uji Autokorelasi Setelah} Transformasi

\begin{tabular}{|l|r|r|r|r|r|}
\hline Model & Rodel Summaryb \\
\hline 1 & .6728 & R Square & $\begin{array}{c}\text { Adjusted R } \\
\text { Square }\end{array}$ & $\begin{array}{c}\text { Std. Error of the } \\
\text { Estimate }\end{array}$ & Durbin-Watson \\
\hline a. Predictors: (Constant), LN_PER, LN_DER, LN_DPR, LN_WCTO & .56880 & 1.961 \\
b. Dependent Variable: LN_PBV
\end{tabular}

Berdasarkan tabel uji autokorelasi diatas, dapat disimpulkan bahwa nilai DW sebesar 1,961, dengan melihat tabel uji durbin - watson dapat tingkat signifikan $5 \%$ untuk jumlah variabel bebas $=4$ dan jumlah sampel $=80$ diperoleh nilai $\mathrm{du}=$ 1,7430 dan $\mathrm{dl}=1,5337$, sehingga dapat disimpulkan bahwa data terbebas dari masalah autokorelasi karena $\mathrm{du}<\mathrm{dw}<4$ $\mathrm{du}(1,7430<1,961<2,257)$.

\subsubsection{Uji Heterokedastisitas}

Bertujuan untuk menguji apakah dalam model regresi terjadi ketidaksamaan varian dari residual suatu pengamatan ke pengamatan yang lain (Ghozali, 2011). Pendeteksian ada tidaknya heteroskedastisitas dapatjuga dilakukan dengan menggunakan metode uji Glejser, yaitu dengan cara mengregresikan nilai 
absolut residual terhadap variabel independen.

Tabel 6. Uji Glejser Setelah Transformasi Coefficients $^{a}$

\begin{tabular}{|c|c|c|c|c|c|c|}
\hline \multirow{2}{*}{\multicolumn{2}{|c|}{ Model }} & \multicolumn{2}{|c|}{$\begin{array}{l}\text { Unstandardized } \\
\text { Coefficients }\end{array}$} & \multirow{2}{*}{\begin{tabular}{|c|}
$\begin{array}{c}\text { Standardized } \\
\text { Coefficients }\end{array}$ \\
Beta \\
\end{tabular}} & \multirow[t]{2}{*}{$\mathrm{t}$} & \multirow[t]{2}{*}{ Sig. } \\
\hline & & $B$ & Std. Error & & & \\
\hline \multirow{5}{*}{1} & (Constant) & .861 & .250 & & 3.435 & .001 \\
\hline & LN_DER & .134 & .074 & .293 & 1.815 & .074 \\
\hline & LN_WCTO & -.075 & .072 & -.162 & -1.045 & .299 \\
\hline & LN_DPR & .091 & .073 & .163 & 1.244 & .217 \\
\hline & LN PER & -.051 & .069 & -.084 & -.742 & .461 \\
\hline
\end{tabular}

Berdasarkan tabel uji glejser diatas menunjukkan bahwa nilai signifkan variabel debt to equity ratio sebesar 0,074 ; working capital turnover sebesar 0,299; dividend payout ratio sebesar 0,217; dan price earning ratio sebesar 0,461 lebih besar dari 0,05, sehingga dapat disimpulkan tidak terjadi masalah heterokedastisitas.

\subsection{Hasil Analisis Data Penelitian}

Pengujian hipotesis yang digunakan dalam penelitian adalah dengan menggunakan analisi regresi linier berganda. Model regresi yang digunakan adalah sebagai berikut :

Berdasarkan tabel diatas diperoleh rumus regresi sebagai berikut :

\section{Tabel 7. Persamaan Regresi}

Coefficients $^{\mathrm{a}}$

\begin{tabular}{|c|c|c|c|c|c|c|}
\hline \multirow[t]{2}{*}{ Mode } & & \multicolumn{2}{|c|}{$\begin{array}{l}\text { Unstandardized } \\
\text { Coefficients }\end{array}$} & \multirow{2}{*}{$\begin{array}{c}\begin{array}{c}\text { Standardized } \\
\text { Coefficients }\end{array} \\
\text { Beta }\end{array}$} & \multirow[t]{2}{*}{$t$} & \multirow[t]{2}{*}{ Sig. } \\
\hline & & $B$ & Std. Error & & & \\
\hline \multirow{5}{*}{1} & (Constant) & -.711 & .405 & & -1.757 & .083 \\
\hline & LN_DER & .196 & .119 & .203 & 1.653 & .102 \\
\hline & LN_WCTO & -.125 & .117 & -.127 & -1.070 & .288 \\
\hline & LN_DPR & .366 & .118 & .310 & 3.093 & .003 \\
\hline & LN_PER & .838 & .112 & .649 & 7.478 & .000 \\
\hline
\end{tabular}

LN_PBV $=-0,711+0,196$ LN_DER 0,125 LN_WCTO + 0,366 LN_DPR + 0,838 LN_PER

Makna dari persamaan regresi linier berganda diatas adalah :
1. Nilai konstanta sebesar $-0,711$ artinya jika variabel debt to equity ratio, working capital turnover, dividend payout ratio, dan price earning ratio dianggap nol atau tidak, maka nilai perusahaan adalah sebesar 0,711 satuan.

2. Nilai koefisien regresi debt to equity ratio sebesar 0,196 menyatakan bahwa setiap kenaikan debt to equity ratio satu satuan akan menyebabkan peningkatan nilai perusahaan sebesar 0,196 satuan.

3. Nilai koefisien regresi working capital turnover adalah -0,125 menyatakan bahwa setiap kenaikan working capital turnover satu satuan akan menyebabkan penurunan nilai perusahaan sebesar 0,125 satuan.

4. Nilai koefisien regresi dividend payout ratio adalah 0,366 menyatakan bahwa setiap kenaikan dividend payout ratio satu satuan akan menyebabkan peningkatan nilai perusahaan sebesar 0,366 satuan.

5. Nilai koefisien regresi price earning ratio adalah 0,838 menyatakan bahwa setiap kenaikan price earning ratio satu satuan akan menyebabkan peningkatan nilai perusahaan sebesar 0,838 satuan.

\subsection{Koefisien Determinasi Hipotesis}

Uji koefisien determinasi dilakukan untuk mengukur seberapa besar kemampuan varian dan variabel bebas dapat menjelaskan variabel terikat. Nilai koefisien determinasi yang semakin besar, maka semakin besar kemampuan variabel bebas dalam menerangkan variabel terikat.

Tabel 8. Koefisien Determinasi

\begin{tabular}{|l|r|r|r|r|}
\hline Model & \multicolumn{1}{|c|}{ Model Summary } \\
\hline 1 & R Square & $\begin{array}{c}\text { Adjusted R } \\
\text { Square }\end{array}$ & $\begin{array}{c}\text { Std. Error of the } \\
\text { Estimate }\end{array}$ \\
\hline
\end{tabular}
a. Predictors: (Constant), LN_PER, LN_DER, LN_DPR, LN_WCTO
b. Dependent Variable: LN_PBV


Berdasarkan hasil uji koefisien determinasi diatas diperoleh nilai Adjusted $R$ Square $\left(\mathrm{R}^{2}\right)$ koefisien determinasi sebesar 0,422 atau sebesar $42,2 \%$. Hal ini berarti $42,2 \%$ dari variasi variabel nilai perusahaan dapat dijelaskan oleh variabel independen debt to equity ratio, working capital turnover, dividend payout ratio dan price earning ratio dan sisanya sebesar $57,8 \%$ dijelaskan oleh variabel - variabel lain diluar dari variabel yang diteliti seperti earning per share, ukuran perusahaan, dan current ratio.

\subsection{Uji Secara Simultan (Uji F)}

Menunjukkan apakah semua variabel independen berpengaruh secara bersama - sama terhadap variabel dependen.

Tabel 9. Uji Statistik F

\begin{tabular}{|c|c|c|c|c|c|c|}
\hline \multicolumn{7}{|c|}{ ANOVA $^{a}$} \\
\hline & & $\begin{array}{l}\text { Sum of } \\
\text { Squares }\end{array}$ & Df & $\begin{array}{l}\text { Mean } \\
\text { Square }\end{array}$ & $F$ & Sig. \\
\hline \multirow{3}{*}{1} & Regression & 19.955 & 4 & 4.989 & 15.420 & $.000^{b}$ \\
\hline & Residual & 24.265 & 75 & .324 & & \\
\hline & Total & 44.220 & 79 & & & \\
\hline
\end{tabular}

Berdasarkan tabel uji $\mathrm{F}$ diatas diperoleh uji signifikan simultan menghasilkan $F_{\text {hitung }}$ sebesar 15,420 dengan nilai signifikan 0,000 ; sedangkan nilai $\mathrm{F}_{\text {tabel }}$ adalah sebesar 2,49 dengan nilai signifikan 0,05 . Dengan demikian maka $F_{\text {hitung }}>F_{\text {tabel }}$ yaitu $15,420>2,49$, sehingga dapat disimpulkan bahwa variabel debt to equity ratio, working capital turnover, dividend payout ratio, dan price earning ratio secara bersama - sama berpengaruh signifikan terhadap nilai perusahaan pada perusahaan consumer goods industry yang terdaftar di Bursa Efek Indonesia tahun 2014 - 2018.

\subsection{Uji Secara Parsial (Uji-t)}

Menunjukkan pengaruh variabel independen secara individual terhadap variabel dependen.

\section{Tabel 10. Uji t}

Coefficients

\begin{tabular}{|c|c|c|c|c|c|c|}
\hline \multirow[t]{2}{*}{ Mode } & & \multicolumn{2}{|c|}{$\begin{array}{l}\text { Unstandardized } \\
\text { Coefficients }\end{array}$} & $\begin{array}{c}\text { Standardized } \\
\text { Coefficients }\end{array}$ & \multirow[t]{2}{*}{$\mathrm{t}$} & \multirow[t]{2}{*}{ Sig. } \\
\hline & & B & Std. Error & Beta & & \\
\hline \multirow{5}{*}{1} & (Constant) & -.711 & .405 & & -1.757 & $.0 \varepsilon$ \\
\hline & LN_DER & .196 & .119 & .203 & 1.653 & .10 \\
\hline & LN_WCTO & -.125 & .117 & -.127 & -1.070 & .28 \\
\hline & LN_DPR & .366 & .118 & .310 & 3.093 & .00 \\
\hline & LN_PER & .838 & .112 & .649 & 7.478 & .00 \\
\hline
\end{tabular}

a. Dependent Variable: LN_PBV

Berdasarkan pada tabel uji t bahwa :

1. Variabel debt to equity ratio mempunyai $t_{\text {hitung }}$ sebesar 1,653 dengan nilai signifikan 0,102; sedangkan $t_{\text {tabel }}$ adalah sebesar 1,99210 dengan nilai signifikan 0,05 . Dengan demikian thitung $>$ $t_{\text {tabel, }}$ yaitu $1,653<1,99210$, sehingga dapat ditarik kesimpulan bahwa variabel debt to equity ratio secara parsial tidak berpengaruh positif dan signifikan terhadap nilai perusahaan pada perusahaan consumer goods industry yang terdaftar di Bursa Efek Indonesia tahun $2014-2018$.

2. Variabel working capital turnover mempunyai $t_{\text {hitung }}$ sebesar -1,070 dengan nilai signifikan 0,288; sedangkan $t_{\text {tabel }}$ adalah sebesar 1,99210 dengan nilai signifikan 0,05 . Dengan demikian $-t_{\text {hitung }}>-$ $\mathrm{t}_{\text {tabel, }}$ yaitu -1,070>-1,99210, sehingga dapat ditarik kesimpulan bahwa variabel working capital turnover secara parsial tidak berpengaruh negatif dan signifikan terhadap nilai perusahaan pada perusahaan consumer goods industry yang terdaftar di Bursa Efek Indonesia tahun 2014 - 2018.

3. Variabel dividend payout ratio mempunyai $t_{\text {hitung }}$ sebesar 3,093 dengan nilai signifikan 0,003 ; sedangkan $t_{\text {tabel }}$ adalah sebesar 1,99210 dengan nilai 
signifikan 0,05. Dengan demikian $t_{\text {hitung }}>$ $t_{\text {tabel, }}$ yaitu 3,093>1,99210, sehingga dapat ditarik kesimpulan bahwa variabel dividend payout ratio secara parsial berpengaruh positif dan signifikan terhadap nilai perusahaan pada perusahaan consumer goods industry yang terdaftar di Bursa Efek Indonesia tahun $2014-2018$.

4. Variabel price earning ratio mempunyai thitung sebesar 7,478 dengan nilai signifikan 0,000 ; sedangkan $t_{\text {tabel }}$ adalah sebesar 1,99210 dengan nilai signifikan 0,05 . Dengan demikian $t_{\text {hitung }}>$ $t_{\text {tabel}}$, yaitu 7,478 $>1,99210$, sehingga dapat ditarik kesimpulan bahwa variabel price earning ratio secara parsial berpengaruh positif dan signifikan terhadap nilai perusahaan pada perusahaan consumer goods industry yang terdaftar di Bursa Efek Indonesia tahun 2014 - 2018.

\subsection{Pembahasan Pengaruh Variabel Leverage Terhadap Nilai Perusahaan}

Hasil penelitian ini menunjukkan bahwa leverage secara parsial tidak berpengaruh siginifikan terhadap nilai perusahaan pada perusahaan consumer goods industry yang terdaftar di Bursa Efek Indonesia tahun 2014 - 2018. Hasil penelitian ini sejalan penelitian (Nurminda, Isynuwardhana, \& Nurbaiti, 2017) yang mengungkapkan bahwa leverage (DER) tidak memiliki pengaruh signifikan terhadap nilai perusahaan (PBV). Akan tetapi, bertolak belakang dengan penelitian (Sutama \& Lisa, 2018) yang mengungkapkan bahwa leverage berpengaruh positif dan signifikan terhadap nilai perusahaan. Hal ini dikarenakan investor tidak terlalu memperhatikan besar kecilnya hutang yang terdapat di dalam sebuah perusahaan dalam memperbesar nilai perusahaan karena investor cenderung melihat penggunaan dana yang dilakukan oleh manajemen secara optimal dalam meningkatkan nilai perusahaan

\subsection{Pembahasan Pengaruh Working Capital Turnover Terhadap Nilai Perusahaan}

Hasil penelitian ini menunjukkan bahwa working capital turnove rsecara parsial tidak berpengaruh signifikan terhadap nilai perusahaan pada perusahaan consumer goods industry yang terdaftar di Bursa Efek Indonesia tahun 2014 - 2018. Hasil penelitian ini sejalan dengan penelitian (Warouw, Nangoy, \& Saerang, 2016) yang mengungkapkan bahwa perputaran modal kerja tidak berpengaruh signifikan terhadap nilai perusahaan. Akan tetapi, bertolak belakang dengan penelitian (Senja \& Wahyuni, 2017) yang mengungkapkan bahwa perputaran modal kerja berpengaruh negatif dan signifikan terhadap nilai perusahaan. Hal ini dikarenakan modal kerja yang diinvestasikan pada komponen aset yang terdapat di dalam perusahaan masih belum mengalami perubahan atau dapat dikatakan masih dalam keadaan stabil serta perputaran yang terjadi juga relatif stabil sehingga tidak memengaruhi perubahan penjualan maupun laba. Dengan demikian, perusahaan diharuskan memiliki kemampuan dalam menggunakan modal kerja secara optimal dalam memperbesar laba agar nilai perusahaannya dapat tercermin.

\subsection{Pembahasan Pengaruh Kebijakan Dividen Terhadap Nilai Perusahaan}

Hasil penelitian menunjukkan bahwa kebijakan dividen secara parsial berpengaruh positif dan signifikan terhadap nilai perusahaan pada perusahaan consumer goods industry yang terdaftar di Bursa Efek 
Indonesia tahun 2014 - 2018. Hasil penelitian ini sejalan dengan penelitian (Sartini, L. P. N., \& Purbawangsa, I. B. A, 2014) yang mengungkapkan bahwa kebijakan dividen berpengaruh positif terhadap nilai perusahaan. Akan tetapi, bertolak belakang dengan penelitian (Sofia \& Farida, 2017) yang menungkapkan bahwa kebijakan dividen secara parsial tidak ada pengaruh yang signifikan terhadap nilai perusahaan. Hal ini menjelaskan bahwa semakin positifnya nilai perusahaan di mata investor didorong dengan adanya pembagian dividen dalam proporsi yang besar bagi pemegang saham. Umumnya pembagian dividen lebih disukai investor sehingga menyebabkan adanya ketertarikan investor terhadap saham yang beredar di perusahaan dimana jumlah permintaan terhadap saham akan semakin banyak. Dengan demikian, meningkatnya permintaan investor terhadap saham perusahaan akan menimbulkan naiknya harga saham dan nilai perusahaan.

\subsection{Pembahasan Pengaruh Price Earning Ratio Terhadap Nilai Perusahaan}

Hasil penelitian menunjukkan bahwa price earning ratio secara parsial berpengaruh positif dan signifikan terhadap nilai perusahaan pada perusahaan consumer goods industry yang terdaftar di Bursa Efek Indonesia tahun 2014 - 2018. Hasil penelitian ini sejalan dengan penelitian (Lebelaha, D. L. A., \& Saerang, I. S, 2016) yang mengungkapkan bahwa price earning ratio memiliki pengaruh yang signifikan terhadap nilai perusahaan. Akan tetapi, bertolak belakang dengan penelitian (Languju, O., Mangantar, M., \& Tasik, H. H. D, 2016) yang mengungkapkan bahwa price earning ratio tidak berpengaruh signifikan terhadap nilai perusahaan. Hal ini menjelaskan bahwa prospek perusahaan dimasa mendatang dapat dilihat dari price earning ratio, dimana besarnya price earning ratio mengindikasikan bahwa kinerja yang dilakukan perusahaan dalam memperbesar earnings juga cenderung bagus. Investor pun akan merasa tertarik terhadap perusahaan yang memiliki price earning ratio yang besar dengan melakukan pemodalan dana bagi perusahaan.

\section{KESIMPULAN DAN SARAN \\ 5.1 Kesimpulan}

Berdasarkan hasil penelitian, maka dapat ditarik beberapa kesimpulan sebagai berikut :

1. Secara parsial leverage tidak berpengaruh signifikan terhadap nilai perusahaan pada perusahaan consumer goods industry yang terdaftar di Bursa Efek Indonesia tahun 2014 - 2018.

2. Secara parsial working capital turnover tidak berpengaruh signifikan terhadap nilai perusahaan pada perusahaan consumer goods industry yang terdaftar di Bursa Efek Indonesia tahun $2014-2018$.

3. Secara parsial kebijakan dividen berpengaruh signifikan terhadap nilai perusahaan pada perusahaan consumer goods industry yang terdaftar di Bursa Efek Indonesia tahun 2014 - 2018.

4. Secara parsial price earning ratio berpengaruh signifikan terhadap nilai perusahaan pada perusahaan consumer goods industry yang terdaftar di Bursa Efek Indonesia tahun 2014 - 2018.

5. Secara simultan leverage, working capital turnover, kebijakan dividen dan price earning ratio berpengaruh terhadap nilai perusahaan pada perusahaan consumer goods industry yang terdaftar di Bursa Efek Indonesia tahun $2014-2018$. 


\subsection{Saran}

Beberapa saran yang dapat dikemukakan peneliti berkaitan dengan hasil penelitian ini adalah sebagai berikut :

1. Bagi peneliti selanjutnya, disarankan sebagai bahan referensi untuk penelitian selanjutnya dengan variabel yang berbeda seperti earning per share, ukuran perusahaan, dan current ratio yang dapat mempengaruhi nilai perusahaan.

2. Bagi perusahaan, agar memperhatikan kebijakan dividen dan price earning ratio karena kebijakan dividen dan price earning ratio terbukti mempengaruhi nilai perusahaan.

3. Bagi investor, sebelum membuat keputusan untuk menginvestasikan dananya pada perusahaan consumer goods industry sebaiknya memperhatikan besarnya kebijakan dividen dan price earning ratio karena hasil penelitian menunjukkan variabel tersebut berpengaruh signifikan terhadap nilai perusahaan.

\section{DAFTAR PUSTAKA}

Agusentoso, R. (2017). Pengaruh Struktur Modal, Perputaran Modal Kerja dan Profitabilitas Terhadap Nilai Perusahaan (PBV) Studi Kasus Perusahaan Pertambangan dan Energi di BEI Periode Tahun 2010 2014. Jurnal Pendidikan, Ekonomi, dan Bisnis, 10(4).

Arifianto, M., \& Chabachib, M. (2016). Analisis Faktor - Faktor Yang Mempengaruhi Nilai Perusahaan (Studi Kasus Pada Perusahaan Yang Terdaftar Pada Indeks LQ-45 Periode 2011-2014). Diponegoro Journal of Management, 5(2), 415426.
Chandra, H., \& Djajadikerta, H. (2017). Pengaruh Intellectual Capital, Profitabilitas, dan Leverage Terhadap Nilai Perusahaan Pada Perusahaan Sektor Properti, Real Estate, dan Konstruksi Bangunan Yang Terdaftar Di Bursa Efek Indonesia. Ultima Accounting, 9(2), 1-14.

Ferina, I. S., Tjandrakirana, R., \& Ismail, I. (2015). Pengaruh Kebijakan Dividen, Kebijakan Hutang, Dan Profitabilitas Terhadap Nilai Perusahaan (Studi Pada Perusahaan Pertambangan Yang Terdaftar di BEI Periode 2009-2013). Jurnal Akuntanika, 2(1), 52-66.

Ghozali, I. (2011). Aplikasi Analisis Multivariate Dengan Program IBM SPSS 19. Semarang: Universitas Diponegoro.

Hasna, F. (2014). Pengaruh Tata Kelola Perusahaan, Leverage, dan Profitabilitas Terhadap Nilai Perusahaan. Jurnal Ilmu Manajemen (JIM), 2(2).

Ilhamsyah, F. L., \& Soekotjo, H. (2017). Pengaruh Kebijakan Dividen, Keputusan Investasi, dan Profitabilitas Terhadap Nilai Perusahaan. Jurnal Ilmu \& Riset Manajemen, 6(2).

Languju, O., Mangantar, M., \& Tasik, H. H. D. (2016). Pengaruh Return On Equity, Ukuran Perusahaan, Price Earning Ratio dan Struktur Modal Terhadap Nilai Perusahaan Property And Real Estate Terdaftar 
di Bursa Efek Indonesia. Jurnal Berkala Ilmiah Efisiensi, 16(2).

Lebelaha, D. L. A., \& Saerang, I. S. (2016). Pengaruh Price Earnings Ratio, Debt to Equity Ratio dan Dividend Payout Ratio Terhadap Nilai Perusahaan Pada BUMN Yang Terdaftar di Bursa Efek Indonesia. Jurnal Berkala Ilmiah Efisiensi, $16(2)$.

Noor, M. Y. (2017). Analisis Pengaruh Struktur Modal dan Perputaran Modal Kerja Terhadap Nilai Perusahaan Pada Perusahaan Manufaktur Yang Tercatat Pada Bursa Efek Indonesia. AKMEN Jurnal Ilmiah, 14(2).

Novari, P. M., \& Lestari, P. V. (2016). Pengaruh Ukuran Perusahaan, Leverage, dan Profitabilitas Terhadap Nilai Perusahaan Pada Sektor Properti dan Real Estate. EJurnal Manajemen Universitas Udayana, 5(9).

Nurminda, A., Isynuwardhana, D., \& Nurbaiti, A. (2017). Pengaruh Profitabilitas, Leverage, dan Ukuran Perusahaan Terhadap Nilai Perusahaan (Studi pada Perusahaan Manufaktur Sub Sektor Barang dan Konsumsi Yang Terdaftar di Bursa Efek Indonesia Periode 2012-2015). E-Proceeding of Management, 4(1).

Prasetyorini, B. F. (2013). Pengaruh Ukuran Perusahaan, Leverage, Price Earning Ratio Dan Profitabilitas Terhadap Nilai Perusahaan. Jurnal Ilmu Manajemen (JIM), 1(1).
Rudangga, I. G. N. G., \& Sudiarta, G. M. (2016). Pengaruh Ukuran Perusahaan, Leverage, dan Profitabilitas Terhadap Nilai Perusahaan. E-Jurnal Manajemen Unud, 5(7), 4394-4422.

Sanusi, A. (2012). Metodologi Penelitian Bisnis. Jakarta: Salemba Empat.

Sartini, L. P. N., \& Purbawangsa, I. B. A. (2014). Pengaruh Keputusan Investasi, Kebijakan Dividen, Serta Keputusan Pendanaan Terhadap Nilai Perusahaan Manufaktur di Bursa Efek Indonesia. Jurnal Manajemen, Strategi Bisnis, dan Kewirausahaan, 8(2).

Senata, M. (2016). Pengaruh Kebijakan Dividen Terhadap Nilai Perusahaan Yang Tercatat Pada Indeks LQ-45 Bursa Efek Indonesia. Jurnal Wira Ekonomi Mikroskil : JWEM, 6(1), 73-84.

Senja, A. C., \& Wahyuni, D. U. (2017). Pengaruh WCT, Leverage, dan ROE Terhadap Nilai Perusahaan Properti dan Real Estate. Jurnal Ilmu \& Riset Manajemen, 6(2).

Setyani, A. Y. (2018). Pengaruh Kebijakan Hutang, Kebijakan Dividen, dan Profitabilitas Terhadap Nilai Perusahaan. Jurnal Riset Akuntansi dan Keuangan Fakultas Bisnis, 14(1), 15-24.

Sofia, D. M., \& Farida, L. (2017). Pengaruh Kebijakan Dividen, Kebijakan Hutang, dan Keputusan Investasi Terhadap Nilai Perusahaan Pada Sub Sektor Perdagangan Besar 
Yang Terdaftar di Bursa Efek Indonesia Periode 2010-2014. Jurnal Online Mahasiswa Fakultas (JOM) Bidang Ilmu Sosial dan Ilmu Politik, 4(2), 1-15.

Sugiyono. (2012). Metode Penelitian Kuantitatif, Kualitatif, dan $R \& D$. Bandung: PT Alfabeta.

Sutama, D. R., \& Lisa, E. (2018). Pengaruh Leverage dan Profitabilitas Terhadap Nilai Perusahaan (Studi Pada Perusahaan Sektor Manufaktur Food and Beverage Yang Terdaftar di Bursa Efek Indonesia). Jurnal Sains Manajemen \& Akuntansi, 10(1).

Warouw, C., Nangoy, S., \& Saerang, I. S. (2016). Pengaruh Perputaran Modal Kerja dan Profitabilitas Terhadap Nilai Perusahaan Pada Perusahaan Farmasi di Bursa Efek Indonesia. Jurnal Berkala Ilmiah Efisiensi, 16(2). 